\title{
The hospital discharge as evaluated by patients and their caregivers: an integrative literature review*
}

\author{
A alta hospitalar na avaliação de pacientes e cuidadores: uma revisão integrativa da literatura \\ El alta hospitalario en la evaluación de pacientes y cuidadores: una revisión integrada de la \\ literatura
}

\author{
Marcela Ganzella', Márcia Maria Fontão Zago ${ }^{2}$
}

\begin{abstract}
Objective: To evaluate hospital discharge among patients and their caregivers. Methods: A integrative literature review was performed in the database of Pubmed, CINAHL and Lilacs from 2000 and 2005, focusing on the adult patient discharge and elderly with clinical-surgical problems, published in the English or Portuguese language. Results: The population was made up of 54 publications and the sample was made up of 23 papers, which were sorted into two theme categories: 13 focused on the effectiveness and 10 on the process inefficiency. Concluding remarks: In the subjects standpoints, the effectiveness of the discharge planning stems to the provision of information related to the disease and its treatment, contents suitable to their socioeducational characteristics and needs, through individual educational strategies, visual and written, and suitable communication among professionals, patients, caregivers and services.
\end{abstract}

Keywords: Patient discharge; Caregivers; Patient satisfaction

\section{RESUMO}

Objetivo: Avaliar a alta hospitalar entre pacientes e cuidadores. Métodos: Realizou-se uma revisão integrativa da literatura indexada nas bases de dados Pubmed, CINAHL e Lilacs de 2000 a 2005, focalizando a alta de pacientes adultos e idosos com problemas clínico-cirúrgicos, publicadas em língua inglesa ou portuguesa. Resultados: A população consistiu de 54 publicações e a amostra foi de 23 artigos, que foram classificados em duas categorias temáticas: 13 focalizaram a efetividade e 10 a ineficácia do processo. Considerações finais: Na visão dos sujeitos, a eficácia do planejamento da alta deve-se ao fornecimento de informações relacionadas à doença e tratamento, com conteúdos apropriados às suas características sócio-educacionais e necessidades, por meio de estratégias educacionais individuais, visuais e escritas, e comunicação adequada entre os profissionais, pacientes, cuidadores e serviços.

Descritores: Alta do paciente; Cuidadores; Satisfação do paciente

\section{RESUMEN}

Objetivo: Evaluar el alta hospitalario entre pacientes y cuidadores. Métodos: Se llevó a cabo una revisión integrada de la literatura indexada en las bases de datos Pubmed, CINAHL y Lilacs del 2000 al 2005, enfocando el alta de pacientes adultos y ancianos con problemas clínicoquirúrgicos, publicadas en lengua inglesa o portuguesa. Resultados: La población estuvo constituída de 54 publicaciones y la muestra fue de 23 artículos, clasificados en dos categorías temáticas: 13 enfocaban la efectividad y 10 la ineficacia del proceso. Consideraciones finales: En la visión de los sujetos, la eficacia de la planificación del alta se debe al ofrecimiento de informaciones relacionadas a la enfermedad y tratamiento, con contenidos apropiados a sus características socio-educativas y necesidades, por medio de estrategias educativas individuales, visuales y escritas, y comunicación adecuada entre los profesionales, pacientes, cuidadores y servicios.

Descriptores: Alta del Paciente; Cuidadores; Satisfacción del paciente

\footnotetext{
* Study carried out at Escola de Enfermagem de Ribeirão Preto - Universidade de São Paulo - USP - Ribeirão Preto, (SP), Brażil, as a Research Productivity Project, CNPq no. 302511/2004-0.

1 Student of the Undergraduate Course at Escola de Enfermagem de Ribeirão Preto - Universidade de São Paulo - USP, Ribeirão Preto, (SP), Brazil.

2 Nursing Ph.D; Associate Professor at Escola de Enfermagem de Ribeirão Preto - Universidade de São Paulo - USP, Ribeirão Preto, (SP), Brazil.
} 


\section{INTRODUCTION}

Hospital discharge (HD) is the transference of patient care from the hospital to other health contexts. In the hospital, the doctor is the legal responsible for the patient $\mathrm{HD}$, but the nurse is considered its planning coordinator. The nurse acts wholly with the patient, whereas the other health team members provide eventual interventions ${ }^{(1)}$.

Premature discharge is the strategy of the health systems to fight the high treatment costs that require hospitalization. The burden of resuming the patient care, however, is passed to the patients and their families or caregivers. As a strategy to prepare the patient to assume the responsibility for the resume of care, the World Health Organization points out the patient discharge planning (DP). The DP was developed due to new basic guidelines of the health systems such as the Public Health System (PHS), which relies on values of action and health services completeness ${ }^{(2-4)}$. It is aimed at providing a safe transference, avoiding difficulties to the patient and their caregivers, re-hospitalizations and, consequently, mitigating costs for the health system ${ }^{(1-2,4)}$.

The authors agree that the discharge should be planned by the multiprofessional team in charge of care, and its implementation should start right after the therapeutics establishment ${ }^{(4-5)}$.

Studies $^{(6-9)}$ show that the information provision is the basic DP intervention, and the patients and their caregivers are able to identify their needs of information, which depend on the health status and types of required care for discharge. Nevertheless, the way the information is provided and the resources used may help apprehend its contents and favor process satisfaction.

Regarding the influences of the patient and caregiver social characteristics and the need of DP information, the results are controversial. In a study ${ }^{(8)}$ with 144 patients, the authors identified that women, the elderly, the lonely and patients with low educational background showed higher number of needs of discharge information. Other studies $^{(1,6)}$ showed that there is not association between age, gender, educational background and preferences of DP information.

The patients and their families are key elements for the DP evaluation, by means of process satisfaction or dissatisfaction. Satisfaction refer to an evaluation based on cognitive and affective reactions in relation to structure, process and results of health care services. This reaction results in the comparison of received care with subjective criterion, that is, perception or expectation ${ }^{(10)}$. Thus, DP satisfaction is related to the information provision that met the patients and their family needs, enabling the development of abilities. They feel safe to resume the post-discharge care. DP dissatisfaction has the opposite connotation, that is, the process did not meet the involved people expectations. In this aspect, there is questioning: how do patients and their caregivers evaluate DP? This paper was developed in order to answer such question. This paper is part of a project that attempted to synthesize the DP knowledge published in literature.

\section{OBJECTIVE}

This study aimed at describing how clinical-surgical patients, adults and elderly and caregivers evaluate DP, through papers published in national and international literature, in the 2000 to 2005 period, published in the Portuguese and English language.

\section{METHODS}

An integrative literature review ${ }^{(11)}$ was performed to identify the publications that tackle DP, accessing the electronic databases of Pubmed, CINAHL and Lilacs. The keywords used were "alta do paciente" and "patient discharge"; the search was restricted to the 2000 to 2005 period, to adults and elderly in clinical-surgical situations, and to the English and Portuguese languages.

With different methodological approaches, 54 full publications and 23 of them tackled the focus of the study. All of them were read and the data were collected by means of a validated form, which included the characterization of the publication and the authors, type of study and the results or considerations presented. Through the paper contents, the results were sorted into two theme categories: satisfaction and dissatisfaction with the process, from the patients and their families standpoint, which are presented now.

\section{RESULTS}

\section{Publication characterization}

Of the 23 reviewed papers, $16(70 \%)$ were published in the 2000 to 2002 period, and 7 (30\%) from 2003 to 2005; 9 were originally from the USA, 7 from Europe, 4 from Canada and Australia and 3 were national. They were published in 15 different journals. Two national and 11 about nursing. Eighteen studies had the nurse as one of the authors, with doctors, social assistants and psychologists; four had only doctors and one did not show the authors occupation.

Concerning the patient groups involved, $11(47.8 \%)$ focused exclusively on the elderly with chronic conditions, under clinical or surgical treatment, $5(21.7 \%)$ the surgical patient, $5(21.7 \%)$ the adult clinical-surgical patient with different diseases, one focused on the cancer patients $(4.4 \%)$; one involved only the caregivers of elderly $(4.4 \%)$. 


\section{DP evaluation among patients and their caregivers. \\ DP satisfaction}

Thirteen publications demonstrated DP satisfaction among patients and/or family.

Six papers ${ }^{(12-17)}$ evaluated the DP implementation with information provision regarded as general such as: daily activities, medication resume and medical accompanying (where, how and when). Six other studies $^{(18-24)}$ implemented DP by means of specific educational intervention, aiming at the disease and the required care for treatment resume in the household, and obtained the subjects evaluation. In this group of studies, besides the oral information, written information was provided, with the same contents, considered relevant by the subjects.

In all the studies, the patients and their families demonstrated to be satisfied with DP that they were involved, due to the fact that their expectations were met and the care resume favored.

\section{DP dissatisfaction}

DP dissatisfaction was indicated in ten studies ${ }^{(25-34)}$ developed with qualitative and quantitative methods. In all of them, the information was considered incomplete, mainly that related to the need of medication use resume.

\section{DISCUSSION}

Regarding the frequency and origin of the publications, the theme impacted most starting in 2001, when the USA, Canada the European countries imposed the process as public policy to the health institutions ${ }^{(4)}$.

The fact that 18 publications were produced by nurses, with other professionals, allows us to argue that thus professional is actively engaged to DP. Among the groups of subjects surveyed, it should be mentioned the importance given to the elderly, as a group with higher incidence of chronic conditions and higher rates of hospitalization. A survey showed the decline in the number of hospitalization days in the USA from 7.3 to 5 days in average; the elderly group corresponded to $39.5 \%$ of all the discharges ${ }^{(4)}$. Another important aspect is the inclusion of caregivers in the eight-study sample, which complies with the DP guidelines ${ }^{(1-2)}$.

Of the thirteen studies that demonstrated DP satisfaction, six ${ }^{(12-17)}$ employed descriptive approaches, three with longitudinal orientation ${ }^{(18,20,24)}$, one ${ }^{(19)}$ nearlyexperimental, one ${ }^{(21)}$ experimental, and two ${ }^{(22-23)}$ metanalyses. However, the authors of the two metanalyses ${ }^{(22-23)}$ argue that the studies analyzed showed results with little significant evidences, because of the applied orientation.

Five studies ${ }^{(17-21)}$ showed DP satisfaction stemmed to the educational strategy application which considered the patient health status, that is, information with specific content about the disease and treatment resume, use of audiovisual resources suitable to their educational characteristics. There was an atmosphere that allowed active participation and their expectations were met.

Ten studies ${ }^{(25-34)}$ showed DP dissatisfaction because of the insufficiency of information provided to meet the needs of patients and caregivers. Among them, the studies that applied qualitative approaches ${ }^{(25,33)}$ enabled the understanding of the patient-health professionals relationship, at DP, is crucial for its success.

By the results, it can be inferred that, in the patients and their caregivers standpoint, the factor that favor DP satisfaction are: survey of their information needs and DP elaboration based on this survey; evaluation of their physical, psychological and social conditions; specific disease focus, and therapeutics resume and required care after discharge; active participation in the process; implementation of the teachings, providing oral and written information with the aid of audiovisual resources implemented along the hospitalization, and suitable communication among professionals, subjects, hospital and community services.

The need of information shown by the study subjects are individual and may be different from the priorities established by the health professionals.

It is important to point out that there are several instruments being used to evaluate DP, developed specifically or adapted, little known in Brazilian nursing.

\section{GENERAL CONSIDERATIONS}

This review indicates that, for patients and caregivers, the DP does not fully satisfy. Thirteen studies evaluate this strategy positively, though. Ten studies indicated that the process is not solving the gap between hospital and home care and that the continuation in community services is defective.

Even in countries where DP is health policy emphasized to the health institutions, the process still requires deeper evaluations because it is much of a doctrine or goal, rather than reality. Furthermore, it is clear that this is a process and not an isolated event. Hence, it requires evaluations during the implementation and during the post-discharge period, by the agents and people in charge.

The Brazilian nurses have contributed little for the development of DP knowledge. But the process is recognized by PHS as a strategy for the integrality of care.

As study limitation, it was the impossibility of designing conclusive results (metanalysis) due to orientations and study samples evaluated and the exclusive focus on patients and their caregivers' 
satisfaction. Regarding the second limitation, it is the importance of considering the DP evaluation among health professionals, also active agents in the process, which is our future goal.

Finally, it is important to develop DP nurse

\section{REFERENCES}

1- Huber DL, McClelland E. Patient preferences and discharge planning transitions. J Prof Nurs. 2003;19(4):204-10.

2- Zago MMF. A reabilitação do paciente cirúrgico oncológico do ponto de vista da enfermagem: um modelo em construção [tese]. Ribeirão Preto: Escola de Enfermagem de Ribeirão Preto da Universidade de São Paulo; 2000.

3- Souza MF. Os sinais vermelhos do PSF. São Paulo: Hucitec; 2002.

4- Zwicker D, Picariello G. Discharge planning for the older adult [Internet] EUA: National Guideline Clearinghouse. 2003. p.1-12 [cited 2005 Nov 30]. Available from: http:// www.guideline.gov/summary/summary.aspx?doc_id= $3517 \& \mathrm{nbr}=002743 \& \mathrm{string}=\mathrm{Discharge}+$ AND+planning+AND+older+AND+adult

5- Pearson P, Procter S, Wilcockson J, Allgar V. The process of hospital discharge for medical patients: a model. J Adv Nurs. 2004;46(5):496-505.

6- Anthony MK, Hudson-Barr D. A patient-centered model of care for hospital discharge. Clin Nurs Res. 2004;13(2):117-36.

7- Readding LA. Hospital to home: smoothing the journey for the new ostomist. Br J Nurs. 2005;14(16):S16-20.

8- Johansson K, Hupli M, Salantera S. Patients' learning needs after hip arthroplasty. J Clin Nurs. 2002;11(5):634-9.

9- Ganzella M, Zago MMF. A seleção das informações para o planejamento da alta hospitalar do paciente. Enfermagem Brasil. 2006; 5(5):268-75.

10- Bull MJ, Hansen HE, Gross CB. Predictors of elder and family caregiver satisfaction with discharge planning. J Cardiovasc Nurs. 2000;14(3):76-87.

11- Ganong LH. Integrative reviews of nursing research. Res Nurs Health. 1987; 10(1):1-11.

12- Jacobs V. Informational needs of surgical patients following discharge. Appl Nurs Res. 2000;13(1):12-8.

13- Driscoll A. Managing post-discharge care at home: an analysis of patients' and their carers' perceptions of information received during their stay in hospital. J Adv Nurs. 2000; 31(5):1165-73.

14- Henderson A, Zernike W. A study of the impact of discharge information for surgical patients. J Adv Nurs. 2001;35(3):435-41.

15- Cesar AM, Santos BRL. Percepção de cuidadores familiares sobre um programa de alta hospitalar. Rev Bras Enferm. 2005; 58(6):647-52.

16- Roberts K. Exploring participation: older people on discharge from hospital. J Adv Nurs. 2002;40(4):413-20.

17- Marin MJS, Angerami ELS. Avaliação da satisfação de um grupo de idosas e cuidadores com o planejamento de alta. Rev Bras Enferm. 2000; 53(2):265-73.

18- Davison BJ, Moore KN, MacMillan H, Bisaillon A, Wiens K. Patient evaluation of a discharge program following a radical prostatectomy. Urol Nurs. 2004; 24(6):483-9.

19- Bull MJ, Hansen HE, Gross CR. A professional-patient partnership model of discharge planning with elders hospitalized with heart failure. Appl Nurs Res. 2000; 13(1):19-28.

20- Moore SM, Dolansky MA. Randomized trial of a home competence in undergraduate courses, permanent education and carry on researching the theme by means of different methodological approaches. We believe that this process may ensure treatment adhesion and quality of life to patients and caregivers in the post-discharge.

recovery intervention following coronary bypass surgery. Res Nurs Health. 2001; 24(2):93-104. Comment in: Evid Based Nurs. 2002; 5(1):17.

21- Koelling TM, Johnson ML, Cody RJ, Aaronson KD. Discharge education improves clinical outcomes in patients with chronic heart failure. Circulation. 2005; 111(2):17985.

22- Shepperd S, Parkes J, McClaren J, Phillips C. Discharge planning from hospital to home. Cochrane Database Syst Rev. 2004; (1):CD000313. Review.

23- Phillips CO, Wright SM, Kern DE, Singa RM, Shepperd S, Rubin HR. Comprehensive discharge planning with postdischarge support for older patients with congestive heart failure: a meta-analysis. JAMA. 2004; 291(11):135867. Erratum in: JAMA. 2004; 292(9):1022. Comment in: Evid Based Nurs. 2004; 7(4):115. JAMA. 2004; 291(23):2816; author reply 2816-7.

24- Worth A, Tierney AJ, Watson NT. Discharged from hospital: should more responsibility for meeting patients' and carers' information needs now be shouldered in the community? Health Soc Care Community. 2000; 8(6):398-405.

25- Procter S, Wilcockson J, Pearson P, Allgar V. Going home from hospital: the carer/patient dyad. J Adv Nurs. 2001; 35(2):206-17.

26- Wilson K, Pateman B, Beaver K, Luker KA. Patient and care needs following a cancer-related hospital admission: the importance of referral to the district nursing service. J Adv Nurs. 2002; 38(3):245-53.

27- DesRoches C, Blendon R, Young J, Scoles K, Kim M. Caregiving in the post-hospitalization period: findings from a national survey. Nurs Econ. 2002; 20(5): 216-21, 224.

28- Kemper JA. Pain management of older adults after discharge from outpatient surgery. Pain Manag Nurs. 2002; 3(4):141-53.

29- Forster AJ, Murff HJ, Peterson JF, Gandhi TK, Bates DW. The incidence and severity of adverse events affecting patients after discharge from the hospital. Ann Intern Med. 2003; 138(3):161-7. Comment in: Ann Intern Med. 2003;138(3):I-16. Ann Intern Med. 2004;140(3):231-2; author reply 232-3. Ann Intern Med. 2004;140(3):231; author reply 232-3. Ann Intern Med. 2004;140(3):231; author reply 232-3. Ann Intern Med. 2004;140(3):232; author reply 232-3.

30- Clark PA, Drain M, Gesell SB, Mylod DM, Kaldenberg DO, Hamilton J. Patient perceptions of quality in discharge instruction. Patient Educ Couns. 2005; 59(1):56-8.

31- Kerzman H, Baron-Epel O, Toren O. What do discharged patients know about their medication? Patient Educ Couns. 2005; 56(3):276-82.

32- Miasso AI, Cassiani SHB. Administração de medicamentos: orientação final de enfermagem para a alta hospitalar. Rev Esc Enferm USP. 2005; 39(2):136-44.

33- Efraimsson E, Sandman PO, Hydén LC, Rasmussen BH. Discharge planning: "fooling ourselves?" - patient participation in conferences. J Clin Nurs. 2004;13(5):56270.

34- Centers for Disease Control and Prevention (CDC). 
Division of Cancer Prevention and Control. A National action plan for cancer survivorship: advancing public health strategies [Internet] Bethesda: CDC. 2001 [cited 2005 Mai 18]. Available from: http://www.cdc.gov/cancer. 